\title{
KEHTOLAULUTOPOS NELJÄSSÄ SUOMALAISESSA OOPPERASSA
}

Käsittelen artikkelissani kehtolaulua, joka on alkuperäisen käyttöyhteytensä, lapsen uneen tuudittamisen, lisäksi löytänyt paikkansa niin populaarimusiikista kuin taide- ja näyttämömusiikistakin. Analysoin kehtolaulun ja kuoleman välisiä kytköksiä suomalaisessa oopperassa soveltaen musiikin semantiikan eli merkitysopin piiriin kuuluvaa teoriaa musiikillisista topoksista, jolloin laajempi tutkimuksellinen viitekehykseni on musiikin semiotiikka. Aineistona käytän neljän suomalaisen oopperan, Armas Launiksen Kullervon, Aulis Sallisen Ratsumiehen, Kaija Saariahon Kaukaisen rakkauden sekä Olli Kortekankaan Isän tytön kehtolaulukohtauksia.

\section{Kehtolaulu kansanperinteessä}

Kehtolaulu tai suomalaisittain tuutulaulu (engl. lullaby tai craddle song; saks. Wiegenlied tai Schlaflied; ransk. berceuse; ruots. Vaggvisa; it. ninnananna) on melodiansa näkökulmasta toistolle perustuva, yksinkertainen ja sävyltään rauhoittava laulutyyppi, jonka avulla äidit ovat kautta aikojen tyynnyttäneet tai nukuttaneet lapsiaan. Kehtolaulu voi olla tahtilajiltaan kolmi- tai nelijakoinen ja melodialinjaltaan laskeva. Lisäksi se on usein hidastempoinen ja rytmisesti synkopoitu (Boyd 2010). Tällöin syntyy mielikuva keinuvasta liikkeestä, "kehdon keinuttamisesta". Perinteisissä suomalaisissa kehtolauluissa käytetään pääasiassa mollisävellajeja (Pentikäinen 1990: 179).

Kehtolaulu kuuluu todennäköisesti edelleen kaikkiin maailman musiikkikulttuureihin. Kehtolaulut ovat osa kansanperinnettä, joka on säilynyt suullisena ja elää 
sukupolvesta toiseen (Pentikäinen 1990: 177). Sekä musiikkiin että tekstiin liittyvällä muuntelulla on ollut suuri merkitys kehtolaulutradition säilymisessä (Asplund 1981: 87). Laulujen korkeasta iästä ovat todisteina eräät kehtolaulujen yksittäiset arkaaiset sanat ja sisältö, jotka toisinaan viittaavat jopa vuosisatoja aikaisemmin vallinneisiin elämäntapoihin ja uskomuksiin (Pentikäinen 1990: 178). Varhaisimmat suomalaiset kehtolaulut ovat peräisin keskiajalta, mikä on päätelty runoihin sisältyvistä katolisiin rukouksiin viittaavista yksityiskohdista (Asplund 2006: 118; ks. myös Hosiaisluoma 2003: 407). Ensimmäisen kerran suomalaisen kehtolaulusävelmän merkitsi muistiin italialainen tutkimusmatkailija ja kansanperinteenkerääjä Giuseppe Acerbi vuonna 1802 (Asplund 2006: 121). Toisaalta kehtolaulut kuuluvat myös oman aikamme populaarimusiikkiin. Kuten musiikintutkijat Boman, Heinonen ja Nikkola (2008) ovat osoittaneet, nykykehtolaulu elää ja voi hyvin: esimerkiksi trubaduuri Marja Mattlarin suomalaisesta kansanperinteestä ammentavasta Kehtolaulusta (2000) on heavy metal -sovituksen tehnyt Timo Rautiainen \& Trio Niskalaukaus.

Vaikka kehtolaulu saatetaan esittää hyräillen, siihen sisältyy useimmiten myös runoteksti, joka on säkeistömuotoinen, runomittaa noudattava lauluteksti. Tavallisesti runo käsittelee aihepiirejä, jotka liittyvät lapsen tai hänen läheistensä elämään. Kehtolaulukulttuuria eri maissa tutkinut uskontotieteilijä Juho Pentikäinen (1990: 178) toteaa, että agraariyhteiskunnan monen sukupolven suurtalouksissa lapsen nukuttamisesta ja näin ollen myös kehtolaulujen laulamisesta huolehtivat äidin lisäksi vanhemmat sisarukset, isoäidit, tädit tai muut - yleensä naispuoliset - sukulaiset. Monissa kulttuureissa kehtolaululla on siis ollut varsin käytännöllinen funktio ihmisten jokapäiväisessä elämässä. Lisäksi kehtolaululla on merkitystä myös yksilön varhaisen musiikkisuhteen rakentumisessa. Kuten jo esimerkiksi etnomusikologian pioneeri Alan Lomax (1956: 128) on todennut: lapsen ensimmäinen kontakti musiikkiin syntyy äidin tai naispuolisen sukulaisen laulaessa hänelle kehtolauluja.

\section{Kehtolaulu taidemusiikissa}

Huolimatta arkielämään liittyvästä funktiostaan kehtolaulu on löytänyt paikkansa myös länsimaisessa taidemusiikissa. Taidekehtolauluihin liittyvät esitysmerkinnät viittaavat usein rauhallisuuteen ja hiljaisuuteen, jolloin paljon käytetty esitysmer- 
kintä on tranquillo (it. rauhallisesti). ${ }^{1}$ Jousi- tai orkesteriteoksissa synkopointi toteutetaan usein jousien pizzicato-eleillä. Erityisen suosittuja kehtolaulut ovat olleet romantiikan ajan piano- ja lied-kirjallisuudessa. Frédéric Chopinin Berceusea (op. 57) pianolle voidaan pitää genren prototyyppinä (ks. Hamilton 2010), ja myös esimerkiksi Jean Sibeliuksen tuotannosta löytyy samanniminen pianoteos (Berceuse op. 40, nro 5). Franz Schubertin, Robert Schumannin, Johannes Brahmsin ja Hugo Wolfin lied-tuotannossa esiintyy kymmeniä kehtolauluja (Wiegenlied) (Laura-suomennostietokanta 2010). Pienimuotoisen vokaali- ja kamarimusiikin lisäksi kehtolaulua on käytetty myös romantiikan orkesterimusiikissa. Esimerkiksi Gustav Mahler sisällyttää kehtolaulun kolmanteen sinfoniaansa (Knapp 2003). Myös suomalaisten säveltäjien kamari- ja orkesterimusiikissa kuullaan kehtolauluja. Erityisen tunnettu suomalainen kehtolaulugenren edustaja on Armas Järnefeltin Berceuse, josta on tehty lukuisia sovituksia. Runsaasti kehtolauluja musiikkiinsa on kirjoittanut Uuno Klami (Aho ja Valkonen 2000: 127). Klamin 1930-luvun teoksiin sisältyy esimerkiksi jousiorkesterille kirjoitettu Kehtolaulu (1930), jonka säveltäjä varusti myöhemmin uudella johdannolla ja orkestroi suuremmalle kokoonpanolle. Näillä muutoksilla siitä tuli osa Kalevala-sarjaa, ja se sai nimen Kehtolaulu Lemminkäiselle. (Aho ja Valkonen 2000: 145.) Myös säveltään sinfonia Symphonie enfantine op. 17 sisältää kehtolauluosan.

Taidemusiikkiin siirrettynä kehtolaulu on useimmiten menettänyt alkuperäisen funktionaalisen tehtävänsä, uneen tuudittamisen laulun avulla. Oopperassa sen sijaan kehtolaulu esitetään useimmiten osana draamaan sisältyvää toimintaa, jolloin sen esittävät oopperan henkilöhahmot. Näin siitä on tullut alkuperäisen tehtävänsä näyttämöä varten luotu representaatio. Oopperatutkija Carolyn Abbaten (1991: 5, 49, 119-123, 131-35, 155) käsitteistöä soveltaen tämänkaltaista, näyttämön nyt-hetkessä kuultavaa musiikkinumeroa voidaan kutsua fenomenaaliseksi musiikiksi. Esimerkiksi Don Giovannin serenadi, jonka viettelijä esittää mandoliinilla itseään säestäen oopperan toisessa näytöksessä on fenomenaalinen numero. Oopperan näyttämötoimintaan kuulumatonta musiikkia Abbate nimittää noumenaalisiksi. Jaottelua voidaan soveltaa myös oopperan kehtolauluihin, jolloin voidaan puhua fenomenaalisesta ja noumenaalisesta kehtolaulusta.

\footnotetext{
${ }^{1}$ Esimerkiksi Sallisen Ratsumiehen ja Launiksen Kullervon kehtolaulukohtausten tempomerkintä on tranquillo.

${ }^{2}$ Abbaten (1991) alkuperäiset englanninkieliset termit ovat phenomenal ja noumenal. Abbaten jako vastaa elokuvamusiikin tutkimuksessa käytettyä jaottelua diegeettinen/ei-diegeettinen musiikki (ks. esim. Välimäki 2008).
} 
Koska oopperassa kehtolaulu liittyy usein uniin tai unennäköön, se on usein myös sijoitettu niin kutsuttuun unikohtaukseen, joka on yksi oopperataiteen vakiintuneista kohtaustyypeistä samoin kuin esimerkiksi hulluus- tai juopottelukohtaus (Rosand 2010). Kehtolauluja on kirjoitettu oopperateoksiin taiteenlajin synnystä saakka. Yksi varhaisimmista oopperakehtolauluista kuullaan Claudio Monteverdin Poppean kruunauksen (kantaesitys 1642) toisessa näytöksessä, jossa Poppean imettäjä Arnalta laulaa kehtolaulun emännälleen. Engelbert Humperdinckin satuoopperassa Hannu ја Kerttu lapset tuudittaa uneen Nukkumatti-hahmo. Edelleen kehtolauluja kuullaan Brittenin Lucretian raiskauksessa, Menotin Konsulissa, Stravinskin Hulttion tiessä ja Gershwinin Porgyssa ja Bessissä. Lisäksi kehtolauluja on kirjoitettu Musorgskin Mazeppaan, Richard Straussin Ariadna auf Naxoseen ja Brittenin Ruuvikierteeseen. Alban Bergin Wozzeckissa naispäähenkilö Marie tyynnyttää poikaansa laulamalla. Oman aikamme teoksista esimerkiksi Harrison Birthwistlen kelttiläiseen Arthur-taruun perustuvaan oopperaan Gawain (1991) on kirjoitettu peräti kolme kehtolaulua. Musiikintutkija David Beardin (2006: 190) mukaan viimeksi mainitussa oopperassa päähenkilön näkemiä painajaisunia yritetään hillitä kehtolaulujen avulla. Huolimatta kehtolaulun erityisestä suosiosta 1800-luvun sävellystyyppinä sen juuret ovat huomattavasti kauempana historiassa. James Porter (2010) toteaakin, että länsimaissa kehtolaulu esiintyy kaikkien aikakausien taidemusiikeissa. Niitä on siis kirjoitettu alkaen barokista oman aikamme musiikkiin ja oopperaan saakka.

\section{Elämä ja kuolema kehtolauluperinteessä}

Niin kansanperinteessä kuin taidemusiikissa kehtolauluun on ajateltu liittyvän pääasiassa elämänmyönteisiä kokemuksia, sillä tekstisisältönsä näkökulmasta tämä laulutyyppi liittyy useimmiten vastasyntyneeseen lapseen, elämän jatkumiseen ja toivoon. Esimerkiksi Italiassa 1600-luvulla alkanut kehtolauluperinne on luonteeltaan valoisa ja toivontäyteinen. Tähän perinteeseen kuuluvia niin kutsuttuja ninnajoulupastoraaleja eli jouluun viittaavia vokaalikehtolauluja esitettiin vastasyntyneen Jeesus-lapsen kunniaksi (Chew 2010). Muun muassa Domenico Cimarosan kehtolaulu Pastorale ossia ninna nanna edustaa tätä traditiota, ja sen on ajateltu olevan Franz Xaver Gruberin tunnetun Stille Nacht, Heilige Nacht -joululaulun (1818) esikuva (Chew 2010). Myös musiikintutkija ja semiootikko Raymond Monelle (2006: 198) liittää kehtolaulun osaksi jo antiikissa kirjalliset muotonsa saanutta paimenten kan- 
soittamaa pastoraalia ja sen musiikillista manifestaatiota, sicilianaa. Kristillisiä sävyjä pastoraali sai Raamatun ajatuksesta, jonka mukaan paimenet näkivät ensimmäisinä vastasyntyneen Jeesus-lapsen ja kerääntyivät seimen ääreen laulamaan kehtolauluja (Monelle 2006: 198). Italialaisessa perinteessä kehto- ja joululaulut näin ollen sekoittuivat. Myös romantiikan ajan kehtolaulurunoissa, kuten Johannes Brahmsin tunnetussa Wiegenliedissä (op. 49, nro 4), runon sanasto ja kielikuvat viittaavat pastoraaliperinteeseen ja ovat luonteeltaan lempeän positiivisia. Laulun toisessa säkeistössä kertoja-äiti toteaa enkelin suojelevan pienokaisen unta. Kokonaisuudessaan Wiegenliedin toisen säkeistön suomennos kuuluu seuraavasti: "Hyvää iltaa, yötä, enkeli vahtii, ja unessasi näät Kristuksen puun: Nuku autuaasti, näe paratiisi" (suom. Juhani Koivisto, ks. Laura-suomennostietokanta 2010).

Uneen tuudittamisen, lapsuuden ja uuden elämän alkamisen lisäksi kehtolaulun teksteihin on joissakin kulttuureissa liitetty kuitenkin myös synkempiä teemoja, kuten kuolema. Uni ja kuolema on yhdistetty toisiinsa jo varhaisessa kirjallisuudessa. Antiikin Kreikan mytologiassa Hypnos ja Thanatos, uni ja kuolema, ovat veljeksiä. Silti esimerkiksi länsieurooppalaiselle kehtolauluperinteelle kuoleman käsittely runoteksteissä on vierasta. Pentikäisen tekemän kyselytutkimuksen mukaan Belgiassa, Ranskassa, Saksassa, Itävallassa ja Sveitsissä ei tunneta esimerkiksi lapsen kuolemasta kertovia kehtolauluja. (Pentikäinen 1990: 183-184.) Tämän voisi ajatella johtuvan kehtolaulun vahvasta siteestä kristilliseen jouluun ja vastasyntyneeseen Jeesukseen Keski-Euroopassa (ks. esim. Monelle 2006). Täysin poissuljettu ajatus kuolemasta eurooppalaisten kehtolaulujen yhteydessä ei kuitenkaan ole. Italialaisia kehtolauluja tutkinut Luisa Del Giudice (1988: 271) tuo esiin myös ninna-laulujen runoihin toisinaan sisältyvän synkemmän sävyn, jolloin äiti ilmaisee kehtolaulussa omaa pelkoaan ja ahdistustaan. Myös Gustav Mahler on käyttänyt kehtolaulumusiikkia viitatessaan lauluissaan nimenomaan lasten kuolemaan (Knapp 2003: 17-18). Silti Euroopassa tunnettu kehtolaulu välittää ennen kaikkea positiivisia, vastasyntyneeseen lapseen ja uuteen elämään, liittyviä tuntoja.

Suomalais-ugrilaisessa runoudessa kehtolaulujen teksteihin sen sijaan sisältyy vahva yhteys kuolemaan, ja erityisesti lapsen menehtyminen on runoissa usein toistuva aihe. Pentikäinen (1990: 190) toteaa, että lapsen kuolemasta tai lapseen kohdistuvasta väkivallasta kertovia kehtolauluja esiintyy suomensukuisilla kansoilla ja itäslaaveilla poikkeuksellisen runsaasti. Kehtolaulujen synkille sävyille ja kuolemaviittauksille on etsitty selitystä muun muassa äitien vaikeista elämäntilanteista. Pentikäinen (1990: 179) toteaa, että koska "pieni lapsi ei ymmärtänyt laulujen syvempää, 
usein vertauskuvallista sanomaa, niissä voitiin käsitellä aiheita, joista muuten välteltiin puhumasta lapsen kuullen". Kehtolauluissa kuoleman jälkeinen elämä toisaalta käsitettiin maallista paremmaksi, joten äiti jopa saattoi toivoa sitä lapselleen (Pentikäinen 1990: 190).

Kuolema- ja väkivaltateeman sisältävät kehtolaulut jaetaan usein lapsen kuolemaan liittyviin surulauluihin sekä uhkauslauluihin, joilla hereillä pysyttelevää lasta pelotellaan väkivallalla, jos hän ei nuku. Surulaulut puolestaan jaetaan kaatuvasta kehdosta kertoviin lauluihin ja hautajaislauluihin. Pentikäinen mainitsee lisäksi "Tuonela-kehtolaulut" omana kuolemaa käsittelevänä kehtolaulutyyppinään. Näissä lauluissa tunnelma on kirjoittajan mukaan alakuloisen ikävöivä, mutta samalla luottavainen, sillä laulajan katse on nöyrästi ylöspäin suuntautunut: lapsi pääsee kuoltuaan taivaan iloihin. Pentikäisen mukaan pessimistisissä suomalaisissa kehtolauluissa lapsi siis tuuditetaan kuoleman uneen. (Pentikäinen 1990: 178-182.) Tällöin uni ja kuolema nähdään toisilleen analogisina. Tämä teema on omaksuttu myös suomalaiseen taiderunouteen. Esimerkiksi Aleksis Kiven (1984 [1870]) Sydämeni laulun ensimmäisessä säkeistössä rinnastuvat yö, kuolema, kehto ja hauta: "Tuonen lehto, öinen lehto! Siell' on hieno hietakehto, sinnepä lapseni saatan" (Kivi 1984: 676-677). Uuno Kailaan viidennen runokokoelman nimi Uni ja kuolema (1931) viittaa samaan tematiikkaan.

\section{Kehtolaulu ja toposteoria}

Tarkastelen artikkelissani kuoleman ja kehtolaulun yhteyttä suomalaisessa oopperassa. Teoreettinen viitekehykseni on musiikin semiotiikka ja sen piiriin sijoittuva musiikin semantiikka eli merkitysoppi (Ratner 1980; Monelle 2000, 2006). Artikkelin keskeinen käsite on alun perin kreikankielen termi topos (mon. topoi), joka musiikintutkimuksessa ymmärretään tunnistettavaksi, rytmis-melodis-soinnilliseksi aiheeksi tai kuvioksi, jolla on semanttinen sisältö (ks. esim. Sivuoja-Gunaratnam 2003; Välimäki 2005; Hautsalo 2008a). Artikkelini keskeisin termi on näin ollen kehtolaulutopos.

Kun jotain tiettyä musiikintyyliä edustava sävelteos sisältää viittauksia toisiin musiikintyyleihin, kuten esimerkiksi Mozartin Don Giovannin toisen näytöksen tanssiaiskohtausta rakentavat erilaiset tanssityylit tai Richard Straussin Ruusuritarin valssiaihe, on kyseessä varsin arkipäiväinen ja jokaiselle tuttu musiikillinen il- 
miö. Teoreettisen ilmauksensa tämä ilmiö on saanut musiikillisessa toposteoriassa, jonka ensimmäisiä muotoilijoita on Leonard Ratner (1980) teoksessaan Classic Music, Expression, Form, and Style. Alun perin kreikankielinen termi topos (mon. topoi) merkitsi paikkakuntaa, seutua tai arkipäiväistä asiaa (Hosiaisluoma 2003). Sama etymologia on myös termeillä topologia ja topografia, jotka viittaavat esimerkiksi paikkoihin, paikantumiseen ja paikantutkimukseen. Musiikillisen toposteorian näkökulmasta määritelmän ilmaus "arkipäiväinen asia" on kuitenkin oleellisin. Tämä viittaa siihen, että jokin musiikillinen aihe tai kuvio on niin tavallinen, että siitä tulee jokapäiväinen, välittömästi tunnistettavissa oleva ja itsestään selvä. Kuulija näin ollen tunnistaa lähes automaattisesti esimerkiksi Don Giovannin menuetin tai Ruusuritarin valssiaiheen. Musiikintutkija Fritz Noske (1977: 172) määrittelee topoksen yksinkertaisesti sukupolvelta toiselle siirtyväksi musiikilliseksi formuloinniksi. Toisin sanoen topos on perinteinen, toistuva ja tunnistettava rytmis-melodinen aihe tai kuvio (Hautsalo 2008a: 70).

Teoriaa musiikillisista topoksista on tähän saakka sovellettu lähinnä klassis-romanttiseen instrumentaalimusiikkiin (Ratner 1980; Allanbrook 1983; Hatten 1994, 2004; Monelle 2000, 2006), mutta viime aikoina myös nykymusiikkia ja vokaalimusiikkia on alettu tarkastella toposteorian näkökulmasta (Hautsalo 2006, 2008a; Torvinen 2007). Vaikka topokset ovat saaneet teoreettisen määrittelynsä vasta 1980- ja 1990-luvulla, niitä on esiintynyt länsimaisessa taidemusiikissa aina. Monelle (2000: 4) toteaa muun muassa suruun ja itkuun viittaavan pianto-topoksen sisältyvän jo 1500-luvun madrigaaleihin, mutta yhtä lailla se hänen mukaansa voi esiintyä myös nykymusiikissa, kuten Kurtagin Stele-teoksessa. Suomessa musiikintutkija Juha Torvinen (2007: 225-236) on tarkastellut pianto-topoksen esiintymistä Erik Bergmanin Colori ed improvvisazioni -teoksessa. Oma tutkimukseni Kaija Saariahon oopperasta Kaukainen rakkaus sisältää modernistisen nykyoopperan laajamittaisen toposanalyysin (Hautsalo 2008a). Toposteoriaa ei ole kuitenkaan merkittävissä määrin sovellettu vokaalimusiikkiin tai oopperaan (vrt. kuitenkin Noske 1977; Allanbrook 1983).

Ratner (1980: 9) jakaa topokset tyyppi- ja tyylitopoksiin, jolloin ensin mainittua edustaa esimerkiksi kokonainen sävellys, kuten esimerkiksi läpisävelletty menuetti, ja jälkimmäistä toiseen teokseen sisällytetty menuettiaihe. Toisaalta topoksia on tarkasteltu myös instrumentaation näkökulmasta, kuten esimerkiksi Philip Tagg (2000) on tehnyt. Jos taidemusiikissa esiintyviä kehtolauluja tarkastellaan Ratnerin kategorioiden näkökulmasta, edellä mainittu Sibeliuksen Berceuse on esimerkki tyyppitopoksesta. Tyylitopos puolestaan sisältyy esimerkiksi säveltäjän pianoteokseen Kyl- 
likki, kolme lyyristä kappaletta op. 41 ja sen Andantino-osaan, jonka voi musiikintutkija Susanna Välimäen (2005: 220) mukaan tulkita "muuntuneeksi kehtolauluksi [twisted lullaby], jonka dynamiikka muistuttaa keinuvaa liikettä".

Musiikkitieteessä taidekehtolaulua on sivuttu aiemmin pastoraalitopokseen liittyvissä tutkimuksissa (Hatten 1994, 2004; Monelle 2000, 2006; Chew 2010), ja myös oopperasta ja kehtolaulusta on kirjoitettu. Väitöskirjassaan The Lullaby in Twentieth-century Opera Roh-Kyoung Park (1997) tarkastelee kehtolauluja ennen kaikkea laulajan näkökulmasta. Kehtolaulua suomalaisessa oopperassa ei kuitenkaan ole tarkasteltu. Kansanperinteeseen sisältyviä kehtolauluja on Suomessa sen sijaan tarkasteltu varsin erilaisten viitekehysten, kuten etnomusikologian, folkloristiikan ja uskontotieteen kautta (ks. esim. Asplund \& Hako 1981; Asplund \& Forstadius 1989; Pentikäinen 1990; Survo 1999). Viime aikoina tutkimusta on tehty myös nykykehtolaulusta, kuten Bomanin, Nikkolan ja Heinosen (2008) edellä mainittu artikkeli trubaduuri Marja Mattlarin kehtolaulusta ja siitä tehdystä sovituksesta osoittaa. Laulaja Sari Kaasinen (2008) on puolestaan käsitellyt kehtolaulua Sibelius-Akatemian Kansanmusiikin osastolle tekemänsä taiteellisen tohtorintutkinnon kirjallisessa työssä Nuku, nuku lapseni: Kehtolauluja ja hyräilyhetkiä. Kehtolaulu kuuluu myös psykologian ja musiikkiterapian tutkimuskohteisiin. Kansainvälisesti kehtolaulua on tutkittu muun muassa kehityspsykologiassa, jossa sillä on nähty olevan merkitystä lapsen kehitykseen erityisesti ensimmäisten ikävuosien aikana (ks. esim. Shenfield, Trehub \& Nakata 2003). Toisaalta kehtolaululla on saatu tuloksia myös musiikkiterapiassa terminaalivaiheessa olevien potilaiden hoidossa (ks. esim. O'Callaghan 2008).

Tarkastelen seuraavassa kehtolaulua suomalaisessa oopperassa. Lähtökohtanani on oletus, että kuolemateema ilmenee suomalaisessa oopperassa periaatteessa samalla tavoin kuin kansallisessa kansanperinteessämme ja kirjallisessa taidekehtolaulussa. Oletan myös, että kuolemateema esiintyy oopperan libreton lisäksi oopperan musiikissa. Kysyn, miten kuolema ilmenee suomalaisen oopperan kehtolauluissa. Rajaan analyysini kohteiksi neljän suomalaisen säveltäjän oopperoissa esiintyvät kehtolaulukohtaukset. Tarkastelun kohteena olevat oopperat ovat Armas Launiksen Kullervo, Aulis Sallisen Ratsumies, Kaija Saariahon Kaukainen rakkaus ja Olli Kortekankaan Isän tyttö. Käsittelen kehtolaulua ennen kaikkea musiikillisena ilmiönä, mutta sivuan sitä myös osana suomalaista kansanrunoutta ja kaunokirjallisuutta. En kuitenkaan tarkastele kehtolauluja kirjallisuudentutkimuksellisen tai librettotutkimuksellisen viitekehyksen kautta, sillä se olisi jo oman erillisen tutkimuksensa aihe. 
Vaikka kehtolaulu saattaa esiintyä myös koomisissa oopperoissa, kuten esimerkiksi Kalevi Ahon satiirisessa Hyönteiselämässä, jonka päätteeksi kuullaan kehtolaulu hilpeiden etanahahmojen esittämänä, analyysin kohteeksi valitsemani teokset ovat luonteeltaan traagisia, minkä lisäksi niitä yhdistää se, että niissä kaikissa miespäähenkilö menehtyy. Valitsemalla tutkimukseni kohteeksi edellä mainitut oopperateokset olen pyrkinyt löytämään analyysiini yhtäl̈ltä mahdollisimman laajaa aikajännettä edustavan teosjatkumon, toisaalta erilaisia musiikillisia tyylejä edustavat

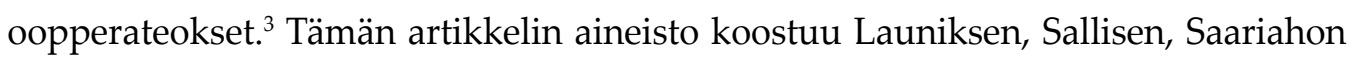
ja Kortekankaan teosten partituureista, sekä Ratsumiehen, Kaukaisen rakkauden ja Isän tytön CD- tai DVD-tallenteista. ${ }^{4}$

\section{Armas Launis: Kullervo}

Varhaisin tässä artikkelissa analysoimistani teoksista on Armas Launiksen (18841959) tragedia Kullervo, joka jatkoi säveltään Seitsemän veljestä -esikoisoopperan suomalaiskansallista teemaa. ${ }^{5}$ Vuonna 1917 Suomalaisessa Oopperassa säveltäjän johdolla kantaesityksensä saanut Kullervo perustuu sekä Kalevalaan ja Kantelettareen että useiden Kalevalaa tuotannossaan soveltaneiden kirjailijoiden teksteihin, kuten Eino Leinon näytelmään Tuonelan joutsen. Tärkein lähde säveltäjän itsensä kirjoittamalle libretolle on kuitenkin Aleksis Kiven Kullervo-näytelmä (Maasalo 1969: 108). Kullervon tarina kertoo inhimillisestä heikkoudesta, kateudesta ja insestistä, ja henkilösuhteidensa näkökulmasta se on analoginen antiikin Oidipus-myytille (ks. esim.

\footnotetext{
${ }^{3}$ Tutkimuksen seuraavassa vaiheessa pyrin laajentamaan analyysiani vielä ainakin kahteen eri aikakausia edustavaan teokseen, Tauno Pylkkäsen Mare ja hänen poikansa -oopperaan (kantaesitys 1945) sekä Einojuhani Rautavaaran oopperaan Aleksis Kivi (kantaesitys 1997). Molemmat oopperat päättyvä miespäähenkilöidensä menehtymiseen ja molempiin loppukohtauksiin sisältyy musiikillinen kehtolaulu.

${ }^{4}$ Kaksi tallenteista on kaupallisia, Deutsche Grammophonen julkaisema DVD-tallenne Kaija Saariahon Kaukaisesta rakkaudesta (Deutsche Grammophon 00440073 4026) vuodelta 2005 sekä levy-yhtiö FINLANDIAN julkaisema CD Sallisen Ratsumiehestä vuodelta 1990. Käytössäni on myös Savonlinnan Oopperajuhlilla tehdyt DVD-taltioinnit sekä vuoden 1975 että vuoden 2005 Ratsumies-produktioista. Ainoastaan Launiksen Kullervosta ei ole olemassa minkäänlaista tallennetta.

${ }^{5}$ Toisen Kullervo-aiheisen suomenkielisen oopperan on kirjoittanut Aulis Sallinen. Sallisen Kullervo sai kantaesityksensä Suomen Kansallisoopperan Yhdysvaltain-vierailulla Los Angelesissa vuonna 1992 (ks. esim. Hako 2002: 215).
} 
Tarasti 1970). Launiksen Kullervo noudattaa sekä Aleksis Kiven samannimistä näytelmää että ottaa aineksia Kalevalasta.

Kalevalan (runot 31-36) mukaan Untamo - Launiksella Unto - on riidan seurauksena tappanut veljensä Kalervon. Kalervon suvusta jää jäljelle vain yksi poika, Kullervo. Väkivahva Kullervo pilaa kaikki hänelle määrätyt työt, ja Untamo myy pojan orjaksi Ilmariselle. Ilmarisen emäntä lähettää Kullervon paimeneen ja leipoo kiven eväsleipään. Leipää leikatessaan Kullervo rikkoo veitsensä, perintökalleutensa, kiveen. Kostoksi Kullervo ajaa lehmät suohon ja pedot karjana kotiin, ja pedot raatelevat lypsylle ryhtyvän emännän kuoliaaksi. Pakeneva Kullervo löytää metsästä vanhempansa mutta kuulee sisarensa kadonneen. Isä lähettää Kullervon veronmaksumatkalle. Paluumatkalla tämä tietämättään viettelee sisarensa. Asian selvittyä sisar hukuttautuu koskeen. Kullervo lähtee kostoretkelle. Surmattuaan Untamon väen hän palaa kotiin mutta tapaa kotiväkensä kuolleina. Kullervo surmaa itsensä.

Oopperan molemmat pohjateokset, Aleksis Kiven Kullervo-näytelmä ja Kalevalan Kullervo-myytti, päättyvät nimihenkilön itsemurhaan, ja myös Launiksen nimihenkilö riistää itseltään hengen. Kullervo-oopperaan sisältyvä kehtolaulutopos kuullaan ennen Kullervon kuolemaa viimeisen kohtauksen (näytös III, kohtaus 2$)^{6}$ alussa, ja sen laulaa Kullervon äiti. Koska äiti esittää laulun osana näyttämön toimintaa kohdistaen sanansa häntä kuuntelevalle Kullervolle, kyseessä on fenomenaalinen kehtolaulu. Laulun päätyttyä Kullervo syöksyy omaan miekkaansa. Yksityiskohtaisessa juoniselostuksessaan Launis (1915: 87) kuvaa oopperan viimeisiä tapahtumia, jotka ennakoivat Kullervon itsemurhaa:

Kullervo tulee. Koston työ on tehty, jäljellä on enää vain kuolon tie. Hän on jo valmis miekkaansa suistumaan, kun etäältä kuuluu äidin vieno kehtolaulu. Kullervo tuntee äänen, joka hänelle muistuttaa menneistä kevätilmoista. Se häntä vielä hetkisen kiinnittää elämään, mutta laulun vaiettua palaavat entiset aatokset ja hän etsii kuolemasta lepoa.

Kullervoon sisältyy myös fantasiaelementti, johon sisältyy maahisia, keijuja ja sinipiikoja (Launis 1915: 84-87). Juoniselostuksessa oopperan viimeinen kohtaus päättyy symbolisiin hautajaisiin. Kuullessaan Kullervo äidin laulun juuri sinipiiat "peittävät hänet [Kullervon] havuilla ja sammalilla" (Launis 1915: 87).

${ }^{6}$ Jatkossa musiikillisten jaksojen sijainti teoksessa osoitetaan lyhennettynä (III/2). 
Kai Maasalon (1969: 110) mukaan tritonussävy on tunnusomaisen voimakas läpi oopperan. "Romanttisen satuoopperan jälkien" lisäksi Maasalo (1969: 108-111) löytää oopperasta "kromaattisia orkesterikulkuja", paimentorvisoolojen luomaa "paimentunnelmaa" sekä esimerkiksi Ajatar-hahmon käärmeloitsussa "ylinousevia intervalleja sekä doorisia säkeitä". Omassa Kullervo-oopperan esittelyssään Launis (1915: 88) nuotintaa teoksensa keskeisimpiä musiikillisia aiheita, kuten Sinipiikain lauluja ja leikki, Kullervon soitto, Nyyrikki, Loitsu ja Sotalaulu. Myös Äidin kehtolaulu mainitaan näiden aiheiden joukossa.

Äidin kehtolaulu (Launis 1995: 202-205; harjoitusnumero 203-206) jakautuu varsinaiseen kehtolauluun sekä lyhyeen 14 tahdista koostuvaan, melismaattiseen itkuvirsi-jaksoon. Maasalon (1969: 110) mukaan Äidin kehtolaulua ja itkuvirttä leimaavat kansalliset ainekset, jotka muualla teoksessa ovat taka-alalla. Kehtolaulu

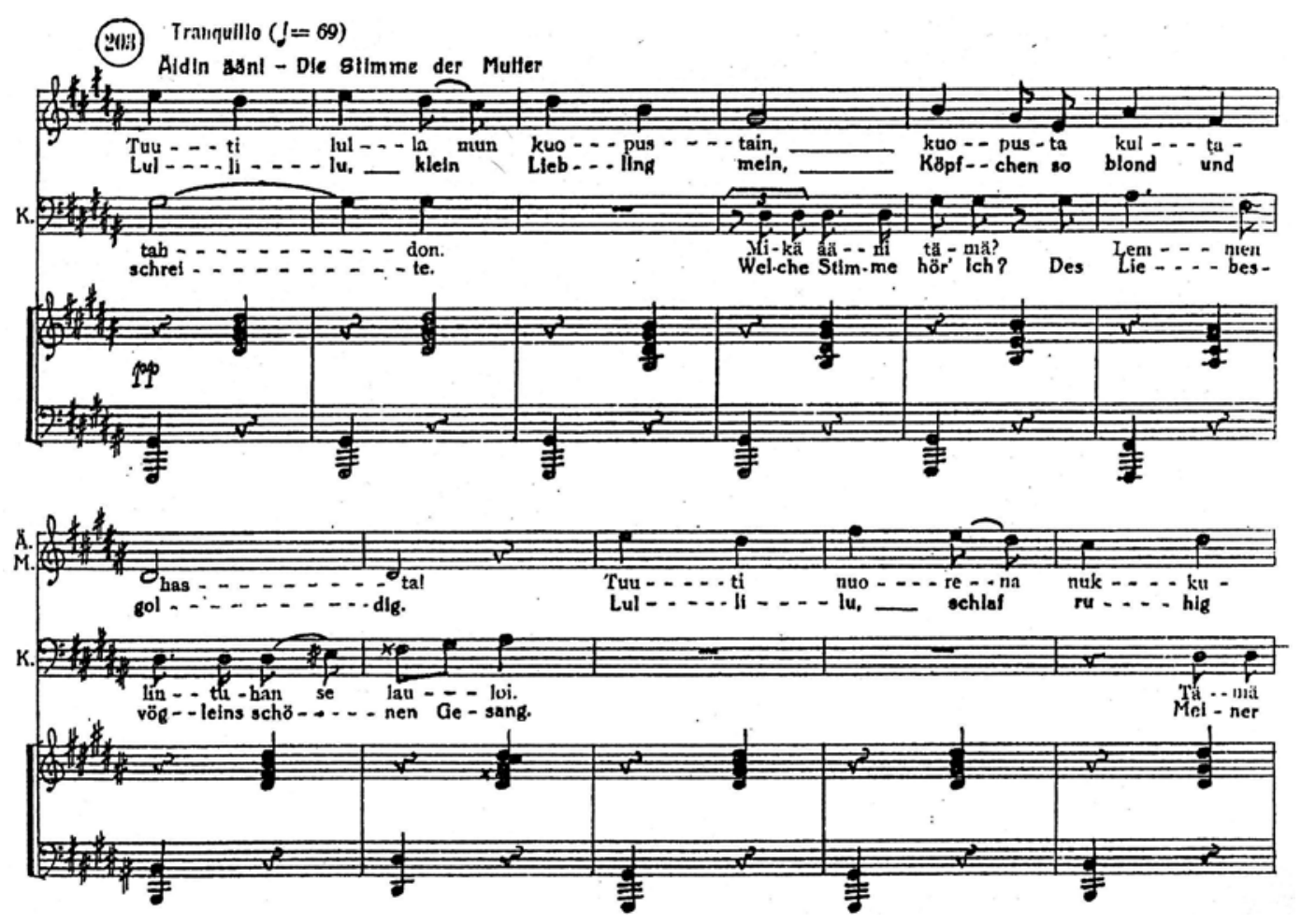

Nuottiesimerkki 1. Armas Launis. Kullervo III näytös, 2. kohtaus. Alkutahdit Kullervon äidin kehtolaulusta (Launis 1995: 202; harjoitusnumero 203). 
etenee fis-mollissa, ja sen rytmi on nelijakoinen (2/4-tahtiosoitus). Esitysmerkinnäksi Launis on kirjoittanut tranquillo, rauhallisesti. Harmonialtaan yksinkertainen, toonika-dominantti-rakenteeseen perustuva kehtolaulu on duettomainen, sillä Kullervo kommentoi äidin sanoja tämän laulaessa lauluaan. Kuoro osallistuu kohtauksen surumielisen tunnelman luomiseen näyttämön takaa.

Kullervon äidin sanat kehtolaulussa mukailevat perinteistä kehtolaulurunoa. Toisessa säkeessä äiti viittaa nuorena nukkumiseen eli kuolemaan, jota toivoo myös pojalleen:
Tuuli lullaa, mun kuopustain, kuopusta kultahasta.
Tuuti nuorena nukkumahan nurjasta maailmasta.
Tuuti lulla mun tummaistani, kuuletko laulun soivan?
Kuuset kotisi ikkunan alla huojuvat surujen hoivan.
Näätkö sä lapseni kuusten alta tähteä tuikkivaista.
Luojan silmä se katsovi sieltä lastani armahaista.
Maailma kiisti mun kuopuksein äityen parmahilta.
Kiitos lapsi kun palasit taasen, myöhä jo onkin ilta.
(Launis 1995: 202-205; harjoitusnumero 203-206.)

Kehtolaulu-runo liittyy kuoleman kahdella tavalla: ensinnäkin sen esittää äiti, joka on jo kuollut. Toisaalta se ennakoi Kullervon poismenoa äidin rinnastaessa nukkumisen ja kuoleman ("nuorena nukkumahan nurjasta maailmasta") ja puhuessa "palaamisesta". Runossa Kullervo siis palaa äitinsä luokse Tuonelaan. Samalla se noudattaa kansanperinteen kehtolauluihin sisältyvää ajatusta kuolemasta paremman tuojana (ks. Pentikäinen 1990). Oopperan päättyessä Kullervo noudattaa äidin kutsua. "Kutsuit orpoa kotiin. Minä tulen", Kullervo toteaa miekkaansa syöksyen (Launis 1995: 207). Voidaan siis sanoa, että Launiksen Kullervossa sekä kehtolaulukohtauksen teksti että musiikki tuovat esiin ajatuksen unen ja kuoleman välisestä analogiasta.

\section{Aulis Sallinen: Ratsumies}

Myös Aulis Sallisen esikoisooppera, uustonaalista tyyliä edustava Ratsumies (19721975) Paavo Haavikon librettoon, päättyy päähenkilönsä ratsumies Antin kuolemaan. Ooppera sai kantaesityksensä Savonlinnan Oopperajuhlilla kesällä 1975 ja aloitti niin kutsutun suomalaisen oopperabuumin (ks. esim. Heiniö 1995, 1999). 
1400-luvulle Listonsaaren kuninkaankartanon maille sijoittuva Ratsumies koostuu kolmesta näytöksestä. Oopperassa ratsumies Antti ja hänen vaimonsa ovat orjina Novgorodissa. Kauppias pakottaa Annan sänkyynsä, ja kostoksi Antti ja Anna polttavat kauppiaan talon, jolloin myös kauppias vaimoineen palaa kuoliaaksi. Pariskunta pakenee Suomeen ja elää henkipattona. Antista kasvaa sortoa vastaan taistelevan talonpoikaisarmeijan päällikkö, mutta taistelu hävitään ja Antti kuolee.

Kuten Kullervossa, myös Ratsumiehessä kehtolaulutopos sisältyy naishahmolle kirjoitettuun musiikkiin, toisin sanoen se on kirjoitettu Ratsumiehen Anna-vaimolle. Tähän kehtolauluun ooppera myös päättyy (III/7). Musiikintutkija Mikko Heiniö (1989: 77) pitää houreen ja mielipuolisuuden lisäksi unennäköä ominaisina 1900-luvun oopperalle. Myös Sallisen oopperassa unella on tärkeä tehtävä oopperan tapahtumissa. Unta käsitellään kahdessa kohtauksessa, jotka sijoittuvat oopperan toiseen ja kolmanteen (viimeiseen) näytökseen. Toisen näytöksen unesta kertova kohtaus on nimeltään "Hän tulee unessa" (Haavikko 1990: 32). Kohtauksessa Annan sanat ovat monitulkintaisia, sillä hän yrittää saada oikeuden uskomaan totuudenvastaisesti, että hänen miehensä on kuollut. Vastauksessaan tuomarille Anna viittaa unennäköön ja siihen, että unia ei voi hallita. "Minä en voi käskeä pois miestä, joka on kuollut. Mitä minä teen miehelle joka tulee unessa?" (Haavikko 1990: 32).

Toinen ja merkittävämpi unta käsittelevä jakso sijoittuu oopperan loppuun (III/7), jossa Anna laulaa Nukkuu se nyt-kehtolaulun kuolleelle miehelleen. Tämä kehtolaulu Launiksen Kullervon kehtolaulun tapaan on fenomenaalinen, sillä se on osa draamaan sisältyvää toimintaa, toisin sanoen luonteeltaan äärimmäisen surumielinen laulunumero. Musiikintutkija Jarmo Anttila (2002: 106-107) löytää kehtolaulun tekstistä suoran alluusion Kalevalan päätösrunoon. Kalevalassa (1951: 726) vastaava tekstipassus kuuluu seuraavasti:

Suuni jo sulkea pitöisi, kiinni kieleni sitoa, laata virren laulannasta, heretä heläjännästä; hevonenki hengästyvi, matkan pitkän mentyänsä, rautanenki raukeavi kesäheinän lyötynsä, vetonenki vierähtävi, joen polvet juostuansa, tulonenki tuikahtavi yön pitkän palettuansa;

Niin miks' ei runo väsyisi, virret vienot vierähtäisi illan pitkiltä iloilta, päivänlaskun laulannoilta? 
Haavikon (1990: 52) kirjoittamassa libretossa Anna toteaa miehestään:

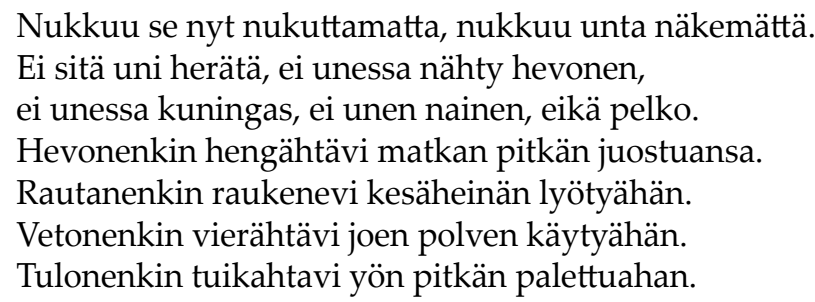

Kalevalan tekstissä keskeinen on ajatus kertojan väsymisestä laulamiseen ja tarpeeseen päättää kertomus: eihän hevonenkaan jaksa loputtomasti. Haavikon tekstissä ajatus unesta ja unennäöstä toistuu, mutta kirjailija käyttää nukkumista eikä Kalevalan tapaan laulamista metaforana elämään väsymiselle ja sen loppumiselle. Unen ja kuoleman välinen analogia käy ilmeiseksi erityisesti ilmauksessa "nukkua nukuttamatta" ja toisaalta ajatuksessa, että mikään, ei edes nainen tai pelko, voi enää herättää ratsumies Anttia.

Anttila (2002: 91) on kutsunut Sallisen sävellystekniikkaa Ratsumiehessä reflektiiviseksi tekniikaksi. Tämä tarkoittaa, että säveltäjä lainaa muiden musiikkia tai käyttää tyylialluusioita, kuten esimerkiksi gregoriaanista laulua. Tämänkaltaisessa musiikillisessa kontekstissa myös kehtolaulun käyttö on perusteltua. Nukkuu se nyt -kehtolaulu on Kullervoon sisältyvän kehtolaulun tavoin rytmiltään tasajakoinen ja synkopoitu. Lisäksi sen sointikuvassa keskeisellä sijalla ovat jouset, joille on kirjoitettu myös pizzicatoja ensimmäiselle tahtiosalle. Sen lisäksi, että Nukkuu se nyt -laululla on siis kehtolaululle ominainen rytmis-melodinen perusluonne, viittaus kehtolauluun on kirjoitettu myös laulua rakentaviin musiikillisiin motiiveihin. Kuten Anttila (2002: 107) toteaa, Nukkuu se nyt -laulussa kerrataan oopperan keskeisiä musiikillisia motiiveja, kuten kohtalomotiivia. Kohtalomotiivi, joka rakentuu kahdesta terssistä, on selvimmin johdettu Aa aa allin lasta -kansansävelmästä (Anttila 2002: 98). Vaikka Aa aa allin lasta -runon kaikissa toisinnoissa kehtolaulun ajatus ei ole selvä, kuitenkin esimerkiksi Otto Kotilaisen Koululauluja-kokoelmassa vuodelta 1924 on laulun sisältyvästä runosta mukana nelisäkeistöinen versio, jossa toisen säkeistön kertosäe "tuuli yksin tummaiselle tuutilaulua laulaa" tuo esiin runon kehtolaulustatuksen "tuutilaulua laulaa" -ilmauksella.

Molemmissa Sallisen Ratsumies-oopperan unikohtauksissa uni ja kuolema siis punoutuvat monitahoisesti yhteen. Nukkuu se nyt -laulussa Sallinen kuitenkin vie yhteenpunoutumisen vielä pidemmälle: käyttämällä yhtäältä kehtolaulumelodiaa 


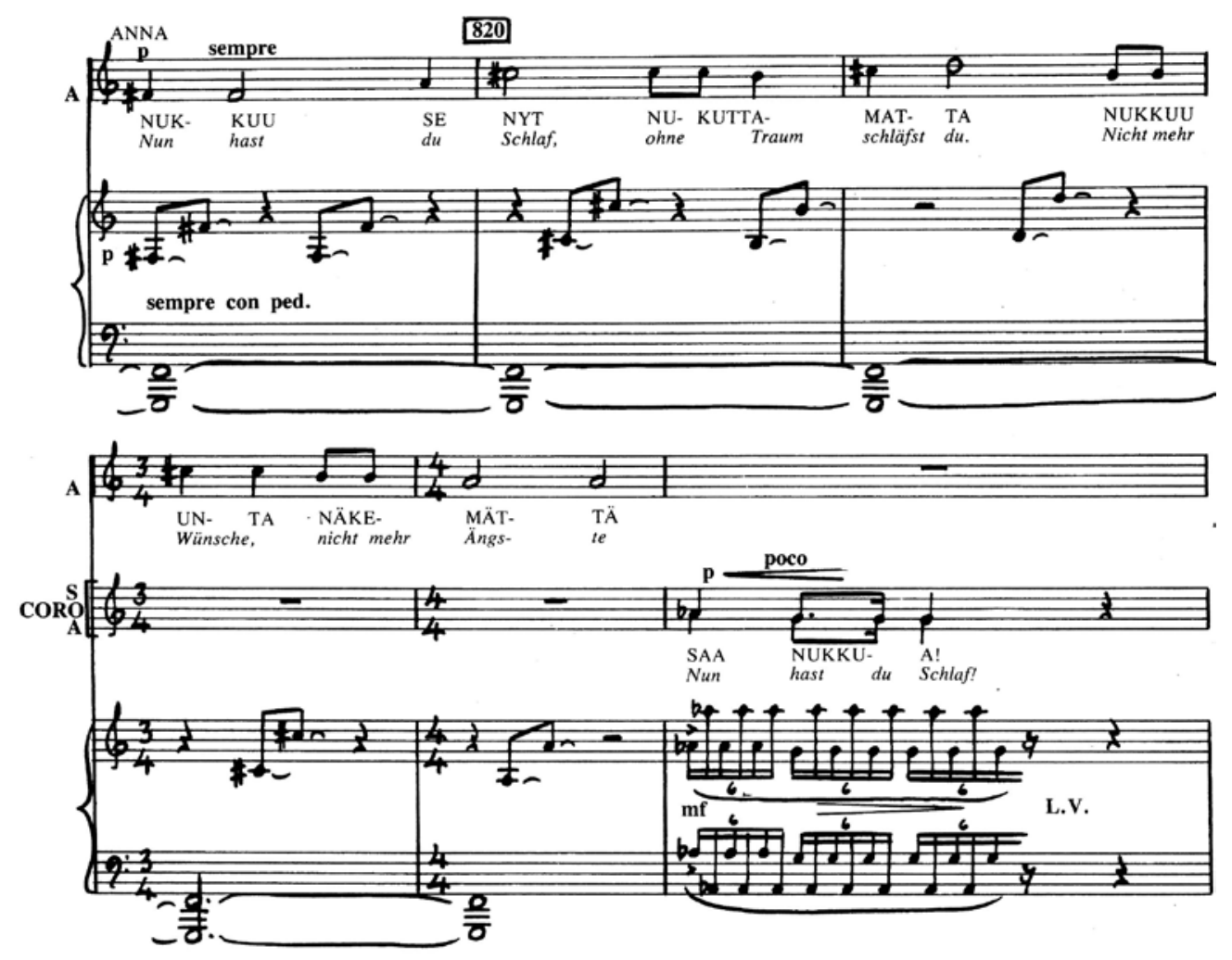

Nuottiesimerkki 2: Aulis Sallinen. Ratsumies III näytös, 6. kohtaus. Alkutahdit Annan kehtolaulusta kuolleelle Ratsumiehelle (Sallinen 1979: 289; tahdit 819-824).

laulun kokonaisvokaalilinjan rakentamisessa ja toisaalta kehtolaulusta peräisin olevaa motiivia yhtenä laulun rakenneosista Sallinen suorastaan alleviivaa oopperassaan Hypnoksen ja Thanatoksen, unen ja kuoleman, ikiaikaista liittoa.

\section{Kaija Saariaho: Kaukainen rakkaus}

Toisin kuin Kullervo ja Ratsumies, Kaija Saariahon miehen ja naisen välisestä saavuttamattomasta rakkaudesta kertova esikoisoopperaa Kaukainen rakkaus (1999-2000) ei suoranaisesti pääty miespäähenkilönsä, oksitanialaisen trubaduuri-ruhtinaan Jaufré Rudelin, kuolemaan. Silti trubaduurin poismeno on oopperan keskeinen tapahtuma ja huipentuma. Viisinäytöksinen Kaukainen rakkaus sai kantaesityksensä Salzburgin 
musiikkijuhlilla elokuussa 2000. Oopperan tilaajina toimivat Salzburgin juhlien lisäksi Châtelet-teatteri Pariisissa ja Santa Fen ooppera Yhdysvalloissa. Libreton teokseen on kirjoittanut Amin Maalouf (s. 1949). Esikoisoopperassaan Saariaho on erkaantunut jälkisarjallisesta sävelkielestä, ja teoksen musiikille ovat ominaisia yhtäältä diatonisuuteen viittaava vokaalitekstuuri, toisaalta laajat vähittäin rakentuvat sointikentät. Saariaholle tyypillisesti merkittävässä osassa oopperassa on elektroniikka. Kaukainen rakkaus on kirjoitettu kolmelle henkilöhahmolle. Jaufré Rudel on kyllästynyt yltäkylläiseen mutta tyhjään elämäänsä. Hän kuulee Pyhiinvaeltajalta meren takana asuvasta naisesta, Tripolin kreivitär Clémencesta. Jaufré rakastuu naiseen Pyhiinvaeltajan kertomuksen perusteella ja lähtee tapaamaan tätä ristiretkeläiseksi tekeytyen. Trubaduuri kuitenkin sairastuu laivamatkalla ja kuolee rakastettunsa käsivarsille satamaan saavuttuaan. Clémence päättää vetäytyä luostariin ja omistaa koko loppuelämänsä Jumalalle. Kaukaisen rakkauden viidennen eli viimeisen näytöksen kuolemakohtausta seuraa vielä kaksi muuta kohtausta (Toivon yhä, [V/3] ja Kohti sinua joka olet niin kaukana [V/4]). Oopperan kehtolaulu siis kuullaan trubaduurin kuoleman yhteydessä oopperan viimeisen näytöksen toisessa kohtauksessa.

Kullervossa ja Ratsumiehessä kehtolauluja laulavat oopperan henkilöhahmot, mutta Kaukaisen rakkauden päähenkilön, Jaufré Rudelin, vähitellen menehtyessä kehtolaulua ei varsinaisesti lauleta, vaan sen esittävät orkesteri ja pianto-topoksilla vahvistettuja foneemeja hyräilevä kuoro. Näin ollen Kaukaiseen rakkauteen sisältyvä kehtolaulutopos ei edusta fenomenaalista vaan noumenaalista kehtolaulua. Kaukaisessa rakkaudessa myös unikohtaus (IV/2) ja kehtolaulu (V/3) ovat erilliset toisin kuten esimerkiksi Sallisen Ratsumiehessä. Neljänteen näytökseen sijoittuvassa unikohtauksessa oopperan päähenkilö, trubaduuri Jaufré Rudel, näkee unta, jossa hänen kaukainen rakastettunsa ilmestyy hänelle. Uni sisältyy oopperan draamalliseen rakenteeseen, jolloin uni visualisoidaan myös näyttämölle (ks. Saariaho 2005). Neljännen näytöksen (IV/2) unikohtauksessa Jaufré näkee unta, jossa Clémence ilmestyy hänelle. Neljästä säkeestä koostuva sitaatti on sijoitettu Clémencen repliikkiin:

Rakkautesi valtaa sieluni

Valveilla ja unessa

Mutta uni on suloisempi

Sillä unessa kuulut minulle!

(Jaufré Rudel, sit. Maalouf 2004: 21).

Tässä lyhyessä jaksossa Jaufrén ja Clémencen vokaalilinjat lomittuvat ja muodostavat kaanonin kaltaista, osittain toisiinsa punoutunutta vokaalilinjaa (Saariaho 2000b: 
268-277; tahdit 263-318). Unen viesti on kuitenkin selvä: rakastavaiset eivät tule kohtamaan toisiaan, vaikka kuolemaan runo ei suoranaisesti viittaa.

Kaukaiseen rakkauteen sisältyvä kehtolaulu sen sijaan viittaa kuolemaan, sillä se kuullaan tilanteessa, jossa sairas Jaufré on kannettu linnoitukseen Tripolissa (Maalouf 2004: 26). Trubaduurin poismenoa ennakoi pehmeä ja hitaasti keinuva 3/4-rytmi, joka toteutetaan pizzicatoin, kuten tapahtuu myös Ratsumiehen kehtolaulussa. Kaukaisessa rakkaudessa kehtolaulurytmi kuitenkin lakkaa vähitellen kuulumasta, kuten myös koko musiikillinen tekstuuri. Olen nimittänyt tätä tekstuurin vähittäistä hiljentymistä ja sammumista haihtumisen eleeksi (Hautsalo 2005, 2006, 2008a). Tämä ele on yksi monista Kaukaiseen rakkauteen sisältyvistä toposteorian mukaisista kuoleman musiikillisista ikoneista (Hautsalo 2008a). Lisäksi viittaus kehtolaulukäytäntöön ja lapsen nukuttamiseen löytyy kohtauksen esitysohjeesta, joka kuuluu: "Kreivitär hyväilee tätä [trubaduuria] niin kuin nukahtanutta lasta" (Maalouf 2004: 30). Myös Kaukaisessa rakkaudessa kuolema ja uni punoutuvat yhteen. Kehtolaulu tuudittaa trubaduuri-ruhtinaan lempeästi ikuiseen uneen (Saariaho 2000b: 345-349; tahdit 235-267).

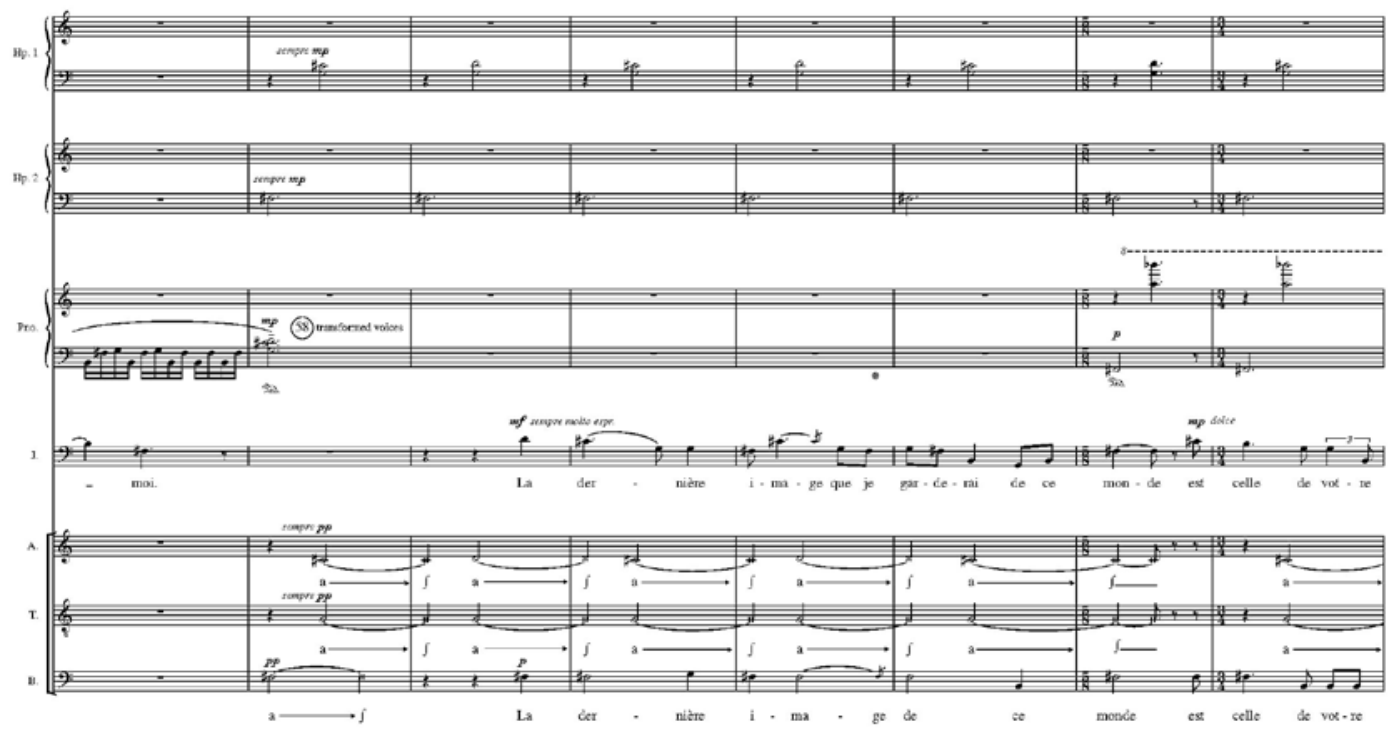

Nuottiesimerkki 3: Kaija Saariaho. Kaukainen rakkaus V näytös, 2. kohtaus. Orkesteri- ja kuorotekstuuria trubaduuri Jaufré Rudelin viimeisiä sanoja säestävästä kehtolaulusta (Saariaho 2000: 247-348, tahdit 234-241). 


\section{Olli Kortekangas: Isän tyttö}

Tarkastelemistani neljästä oopperateoksesta Kortekankaan Isän tytössä kuolemateema ja siihen liittyvä kehtolaulutopos esiintyvät muista teoksista poiketen kompleksisena teoksen ajallisuutta hahmottavana tekijänä. Launiksen Kullervon tavoin myös Olli Kortekankaan Isän tytössä kuolema liittyy kahteen henkilöhahmoon, vanhempaan ja lapseen, jotka ovat naispäähenkilö Anna ja hänen isänsä Urho. Oopperan alkaessa Annan isä on jo kuollut kaaduttuaan rintamalla taistelussa venäläisiä vastaan, ja myös Anna kuolee oopperan kuluessa. Isän tyttöä, joka on säveltäjänsä kuudes oopperateos, voi luonnehtia perhekronikaksi Suomen lähihistoriasta, ja sen tilasi Suomen Eduskunta 100-vuotisjuhlallisuuksiaan varten (Hautsalo 2008b). Teoksen kantaesitys nähtiin Savonlinnan Oopperajuhlilla heinäkuussa 2007. Libreton Isän tyttöön ovat yhteistyössä kirjoittaneet dramaturgi Michael Baran ja säveltää itse. Musiikillisesti Isän tyttö poikkeaa Saariahon Kaukaisesta rakkaudesta tonaalisemman harmoniakäsityksensä sekä perinteisemmän vokaalikirjoituksensa näkökulmista, joten voisi sanoa, että Isän tyttö on ennemminkin Ratsumiehen kuin Kaukaisen rakkauden sukulainen. Kortekankaan teosta määrittävät yhtäältä orkestroinniltaan rikkaat, syvään hengittävät ja jylhät orkesteriosuudet. Toisaalta teoksen musiikilliseen tekstuuriin sisältyy kirpeitä dissonansseja, kromatiikkaa sekä hälyisiä sointikenttiä. (Hautsalo 2008b.)

Isän tyttö on kertomus neljästä naissukupolvesta toisen maailmansodan jälkeisessä Suomessa. Oopperan keskushenkilö on Anna, joka oopperan alkaessa on yhtäkkiä palannut kotiin äitinsä 80-vuotissyntymäpävien aattona lähdettyään viisi vuotta sitten Afrikkaan kertomatta kenellekään. Anna palaa kotiin, koska hän tietää kuolevansa: hän haluaa selvittää asiat, jotka ovat jääneet perheen kanssa selvittämättä. Annan perheen kohtalot esitellään oopperassa takautumien kautta. Ooppera kertoo arvojen muuttumisesta suomalaisessa yhteiskunnassa perheen eri sukupolvia edustavien naisten kautta: Isoäiti Siiri uskoo yrittämiseen ja rakentaa menestyvän idänkauppaa käyvän yrityksen juristityttären edustaessa rauhatonta, itseään taistolaisuudesta ja vapaaehtoistyöstä etsivää kapinasukupolvea. Annan tytär Vera puolestaan perustaa elämänsä 1990-luvun kasinotaloudelle ja koville arvoille. Ruth, Veran ottotytär, sen sijaan edustaa monikulttuurista ja globaalia arvomaailmaa.

Kortekankaan Isän tyttö ei sisällä yhtä ainoaa kehtolaulukohtausta, vaan fragmentteja kehtolaulusta kuullaan useaan otteeseen oopperan kuluessa ja ooppera myös päättyy laajaan kehtolaulun sisältävään koodaan. Ensimmäiseen näytökseen 
sijoittuvat kehtolaulufragmentit ja epilogissa kuultava kehtolaulu koostuvat eri tavoin käytetystä musiikillisesta materiaalista. Sen lisäksi, että kehtolaulu kehystää musiikillisesti oopperan tapahtumia ja toimii myös sen rakenteellisena tukipilarina, se luo teokselle oman semanttisen kuolema-narraationsa. Ensimmäinen kehtolaulu sijaitsee takautumaksi rakennetussa ensimmäisen näytöksen unikohtauksessa, jossa nuori Anna nukahtaa kesken kirjeen lukemisen. Kohtauksessa Anna uneksii isästään Urhosta, joka on kaatunut sodassa (I näytös, 2. kohtaus). Isä ilmestyy Annalle ja jatkaa kirjeen lukemista. Kaksisäkeistöiseksi runoksi rakennettu kirje alkaa puhuttelulla: "Tyttäreni, vastasyntynyt" (Kortekangas 2007: 51; tahdit 402-403). Isän sanoja säestää jousille kirjoitettu 3-jakoinen lempeä kehtolaulu (Kortekangas 2007: 51-53; tahdit 402-423), joka myös kehystää kohtausta rajaten sen ajallisuutta. Jakson päättää post scriptum eli jälkikirjoitus, jossa Urho toteaa: "En tiedä edes nimeäsi, mutta minulle olet aina Anna". Myös näitä sanoja säestää sama, kirjeen alussa kuultu, kehtolauluaihe (Kortekangas 2007: 57-58; tahdit 445-453). Kehtolauluaihe toistuu vielä ensimmäisen näytöksen lopussa oopperan nyt-hetkeen sijoittuvassa kohtauksessa, jossa Anna on aikuinen ja kuolemansairas. Epätoivoisessa tilanteessa Urho ilmestyy Annalle samoin kuin hän oli tehnyt Annan ollessa lapsi. Sama, jo aiemmin kuultu, kehtolauluaihe häivähtää vielä kerran (Kortekangas 2007: 240-242; tahdit 1540-1550), kuitenkin hieman muunneltuna ja sävyltään synkempänä. Uutta ovat luonteeltaan uhkaava patarumpu sekä kirpeät dissonanssit. Kolmannen kerran kehtolaulu kuullaan oopperan epilogissa, jonka tapahtumat sijoittuvat Annan kuoleman jälkeiseen aikaan. Epilogi rakentuu kokonaisuudessaan aiemmasta kehtolaulusta melodis-rytmisesti poikkeavalle kolmijakoiselle kehtolauluaiheelle. Sen esittelevät epilogin alussa puupuhaltimet, jonka jälkeen melodia siirtyy laulusolisteille.

Isän tytön sisältämä kehtolaulumateriaali poikkeaa kolmen edellä analysoidun oopperan kehtolauluista, sillä siinä kuullaan sekä fenomenaalinen eli näyttämön nyt-hetkessä esitetty kehtolaulu että noumenaalisia kehtolaulufragmentteja. Urhon ensimmäisessä näytöksessä laulama kehtolaulu on fenomenaalinen, vaikka sen vastaanottaja, pikku-Anna, nukkuu. Muut Isän tyttöön kirjoitetut kehtolaulut ovat luonteeltaan noumenaalisia.

Isän tytön selkeästi hahmottuva kehtolaulumusiikki yhdistää toisiinsa oopperan henkilöitä ja tapahtumia. Lempeä kehtolaulu liittyy ensinnäkin sodassa kuolleeseen Urhoon sekä Urhon ja hänen Anna-tyttärensä väliseen suhteeseen. Näin ollen kehtolaululla on Isän tytössä myös alkuperäinen lapseen ja elämän jatkumiseen yhdistyvä funktionsa, eikä se viittaa ainoastaan kuolemaan. Yhdistyessään nuoreen Annaan se 
viittaa lapseen, uuteen elämään ja huolenpitoon alleviivaten Annan ja hänen isänsä erityistä suhdetta. Silti kehtolaulu toisen näytöksen lopussa myös tuudittaa sairaan Annan kuoleman uneen. Epilogin kehtolaulun laulavat suvun jäljelle jääneet naiset, Siiri ja Vera. He toistavat oboen esittelemää kehtolauluaihetta kehtolaululle tyypillisten sanojen ja kielikuvien avulla: "Nuku, uinu, ui unen aalloilla, aamun lupausta päin" (Kortekangas 2007: 396-402; tahdit 978-1035). 

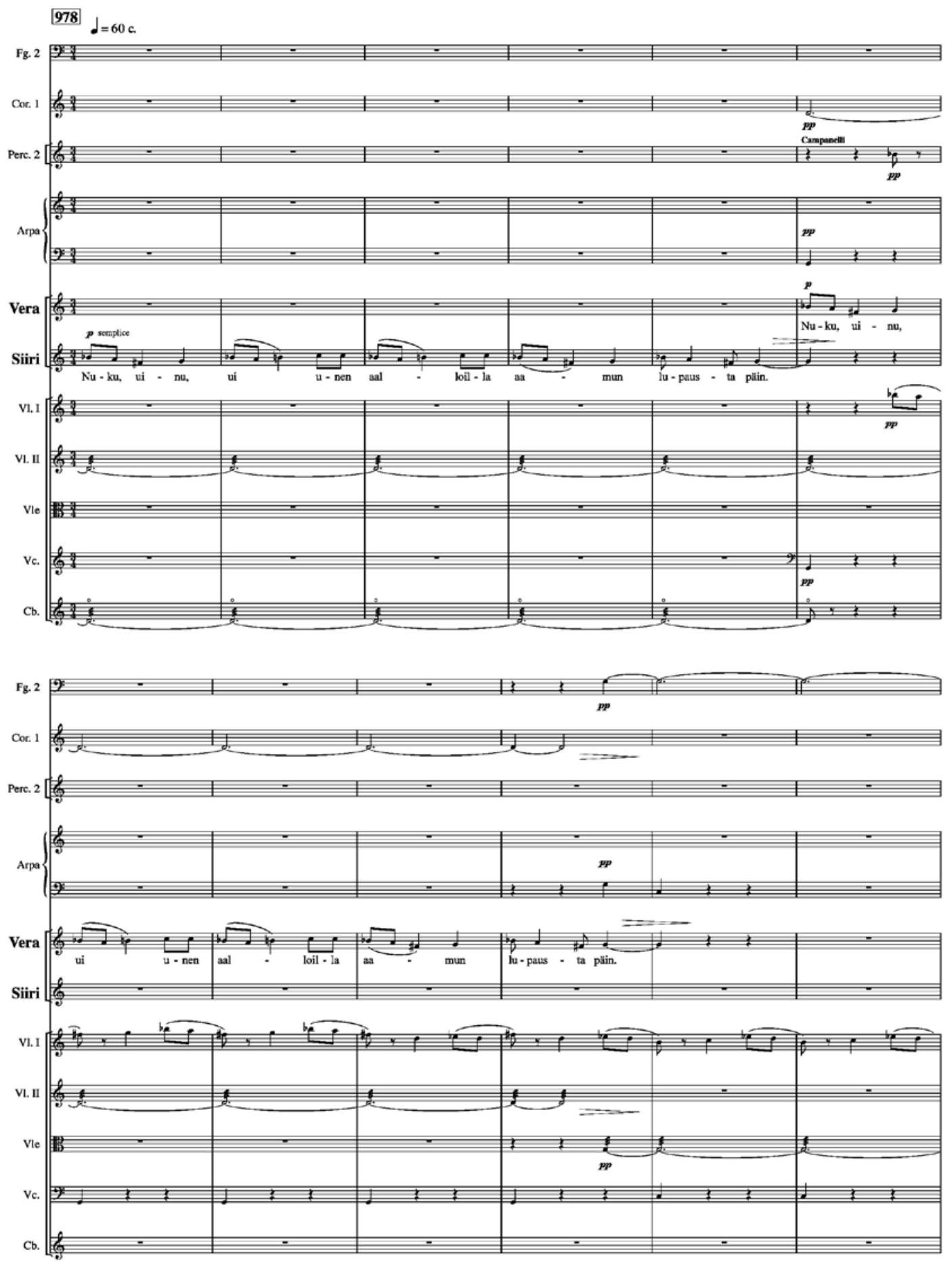

Nuottiesimerkki 4: Olli Kortekangas. Isän tyttö II näytös: Epilogi. Siirin ja Veran oopperan lopussa laulaman kehtolaulun alkutahdit (Kortekangas 2007: 396-397, tahdit 978-989). 


\section{Lopuksi}

Tässä artikkelissa tutkimukseni on kohdistunut neljän suomalaisen oopperan sisältämiin kehtolauluihin, joiden analyysiin olen soveltanut semiotiikan alaan kuuluvaa teoriaa musiikillisista topoksista (Monelle 2000, 2006). Oopperakehtolaulujen kategorisointiin olen käyttänyt Carolyn Abbaten (1991) fenomenaalinen-noumenaalinen -jakoa. Analyysini temaattinen kohde on ollut oopperakehtolaulun yhteys kuolematematiikkaan, jolloin olen tarkastellut sekä kehtolaulujen tekstiä että musiikkia.

Olen osoittanut, että Kullervon ja Ratsumiehen kehtolaulut ovat fenomenaalisia kehtolauluja, joita oopperoiden henkilöhahmot laulavat oopperoiden nyt-hetkessä. Kaukaisen rakkauden kehtolaulu puolestaan edusta noumenaalista kehtolaulua, joka kuullaan osana oopperan kuoro- ja orkesteritekstuuria. Isän tyttö on kehtolaulujen näkökulmasta sekamuoto, sillä siinä kuullaan sekä fenomenaalisia että noumenaalisia kehtolauluja.

Toposteorian näkökulmasta lähtökohtani on ollut Monellen (2006) ja Chew'n (2010) ajatusta seuraten tarkastella kehtolaulutoposta laajan pastoraalitopoksen alatopoksena. Käsitteellä topos olen artikkelissani viitannut eri musiikillisissa konteksteissa tunnistettavuutensa säilyttävään musiikilliseen kehtolauluun, jolloin olen käyttänyt rajatumpaa termiä kehtolaulutopos. Monellen ja Chew'n näkemys kehtolaulusta pastoraalin alatopoksena joudutaan kuitenkin suomalaisen kehtolaulun kohdalla osittain kyseenalaistamaan. Tämä kyseenalaistaminen perustuu suomalaisten kansanrunoudentutkijoiden (Pentikäinen 1990; Asplund 1981) tutkimuksiin.

Suomalaisessa kansanperinteessä usein esiintyvä kehtolaulun kuolema-konnotaatio on, kuten esimerkkini osoittavat, juurtunut myös suomalaiseen oopperaan. Oopperataiteessa kehtolaululla on siis ilmeisen lapsen uneentuudittamisfunktion lisäksi toinen, syvempi, merkityksensä: myös siellä kehtolaulu toimii ikuisen unen eli kuoleman musiikillisena metaforana. Huomionarvoista on myös se, että suomalaisessa oopperassa kehtolaulut eivät liity lapsen kuolemaan, vaan niitä lauletaan aikuisen, yleensä miespäähenkilön, kuoleman yhteydessä. Näyttää siis siltä, kuten analyysini pyrkii omissa rajoissaan osoittamaan, että kehtolaulutopos esiintyy suomalaisissa oopperoissa pääasiassa uni-kuolema-analogian kautta ja näin ollen yhdistyy selvästi kuolemaan ja että suomalaisessa perinteessä kehtolaulu ei liity yhtä selvästi eurooppalaiseen pastoraaliin kuin esimerkiksi Monellen tulkinnassa. Kuten analyysini pyrkii osoittamaan, suomalais-ugrilaisessa perinteessä ja näin ollen myös suomalaisessa oopperassa ainakin analysoimieni neljän teoksen osalta oopperakeh- 
tolaulun juuret ovat pikemminkin kalevalaisessa kuin eurooppalaisessa pastoraaliperinteessä.

Lisäksi artikkelini osoittaa, että kuolematematiikka ei ole ainoastaan librettotekstiin sisältyvä ominaisuus. Analysoimistani teoksista kolmessa, Kullervossa, Ratsumiehessä ja Isän tytössä molemmat, sekä teksti että musiikki, tukevat kuoleman ja unen analogiaa. Huomionarvoista on, että Kaukaisessa rakkaudessa tämä analogia syntyy ainoastaan musiikillisen viittauksen eli kehtolaulutopoksen kautta. Kehtolaululla suomalaisessa oopperassa näyttääkin olevan kahdet kasvot tai kaksoismerkitys. Siinä tiivistyy ikiaikainen ajatus jinistä ja jangista elämästä ja kuolemasta ja niiden välisestä tasapainosta.

\section{Lähteet}

\section{Nuottijulkaisut}

Kortekangas, Olli (2007) Isän tyttö. Oopperan orkesteripartituuri I-II. Savonlinna: Savonlinnan Oopperajuhlat.

Launis, Armas (1995[1917]) Kullervo. Oopperan pianopartituuri. Helsinki: Suomalaisen musiikin tiedotuskeskus.

Saariaho, Kaija (2000) L'Amour de loin (Kaukainen rakkaus). Oopperan orkesteripartituuri II. Lontoo: Chester Music.

Sallinen, Aulis (1979) Ratsumies. Oopperan pianopartituuri. Helsinki: Luovan säveltaiteen edistämissäätiö (LUSES).

Ä̈nite- ja kuvajulkaisut

Kortekangas, Olli (2007) Isän tyttö. Julkaisematon DVD-taltionti Savonlinnan Oopperajuhlien esityksestä. Kirjoittajan hallussa.

Saariaho, Kaija (2005) DVD-tallenne oopperasta Kaukainen rakkaus. Ohjaus Peter Sellars. Musiikinjohto Esa-Pekka Salonen. Deutsche Grammophon 004400734026.

Sallinen, Aulis (1975) Ratsumies. Julkaisematon DVD-taltionti Savonlinnan Oopperajuhlien esityksestä. Kirjoittajan hallussa.

Sallinen, Aulis (2005) Ratsumies. Julkaisematon DVD-taltionti Savonlinnan Oopperajuhlien esityksestä. Kirjoittajan hallussa.

Sallinen, Aulis (1990) Ratsumies. CD-taltiointi. Finlandia Records 1576-51101-2.

\section{Tutkimuskirjallisuus}

Abbate, Carolyn (1991) Unsung Voices. Opera and Musical Narrative in the Nineteenth Century. Princeton: Princeton University Press.

Aho, Kalevi \& Valkonen, Marjo (1999) Uuni Klami: Elämä ja teokset. Helsinki: WSOY.

Allanbrook, Wye Jamison (1983) Rhythmic Gesture in Mozart: Le Nozze di Figaro E Don Giovanni. Chicago: University of Chicago Press.

Anttila, Jarmo (2002) Aulis Sallisen Ratsumies ja Punainen viiva: Oopperaa, musiikkiteatteria ja kulttuuriradikalismia. Jyväskylä Studies in the Arts 81 . Jyväskylä: Jyväskylän yliopisto. 
Asplund, Anneli (2006) Suomen musiikin historia: Kansanmusiikki. Helsinki. WSOY.

Asplund, Anneli \& Forstadius, Annukka (toim.) (1989) Unilintu: Sata suomalaista kehtolaulua. Helsinki: Suomalaisen kirjallisuuden seura.

Asplund, Anneli (1981) "Riimilliset kansanlaulut". Kansanmusiikki. Toim. Anneli Asplund \& Matti Hako. Helsinki: Suomalaisen kirjallisuuden seura.

Beard, David (2006) "The Shadow of Opera: Dramatic Narrative and Musical Discourse in Gawain". Twentieth-century music 2/2, ss. 159-195.

Boman, Sami, Heinonen, Yrjö \& Nikkola, Joni (2008) "Kehtolaulu ja sen taonta raskaaksi metalliksi. Marja Mattlarin ja Timo Rautiainen \& Trio Niskalaukauksen versiot Mattlarin Kehtolaulusta". Musiikin suunta 1, ss. 40-50.

Boyd, Malcolm (2010) "Wiegenlied." Grove Music Online. Oxford Music Online. <http://www.oxfordmusiconline.com/subscriber/article/grove/music/30270>.(luettu 29.10.2010).

Chew, Geoffrey (2010) "Ninna." Grove Music Online. <http://www.oxfordmusiconline.com/subscriber/article/grove/music/19976> (luettu 29.10.2010).

Del Giudice, Luisa (1988) "Ninna-nanna-nonsense? Fears, Dreams, and Falling in the Italian Lullaby". Oral Tradition 3/3, ss. 270-293.

Dällenbach, Lucien (1989 [1977]) The Mirror in the Text. Kääntänyt Jeremy Whitley \& Emma Huges. Cambridge: Polity Press.

Haavikko, Paavo (1990) Ratsumies. Oopperan libretto Finlandia Recordsin julkaisemassa teosesittelyssä. Finlandia Records 1576-51101-2.

Hako, Pekka (2002) Suomalainen oopperamusiikki. Helsinki: BTJ kirjastopalvelu.

Hamilton, Kenneth N. (2010) "Berceuse." Grove Music Online. <http://www.oxfordmusiconline. com/subscriber/article/grove/music/02749>.(luettu 29.10.2010).

Hatten, Robert S. (1994) Musical Meaning in Beethoven: Markedness, Correlation, and Interpretation. Bloomington: Indiana University Press.

Hatten, Robert S. (2004) Interpreting Musical Gesture, Topics, and Tropes: Mozart, Beethoven, Schubert. Bloomington (IN): Indiana University Press.

Hautsalo, Liisamaija (2005). "Transelementit Kaija Saariahon oopperassa Kaukainen rakkaus". Elektronisia unelmia: Kirjoituksia Kaija Saariahon musiikista. Toi. Anne Sivuoja-Gunaratnam. Helsinki: Yliopistopaino. Ss. 231-256.

Hautsalo, Liisamaija (2006). Kerroksellisuus ja transelementit Kaija Saariahon Kaukainen rakkaus -oopperassa. Julkaisematon lisensiaatintutkielma. Helsinki: Helsingin yliopisto, musiikkitiede.

Hautsalo, Liisamaija (2008a) Kaukainen rakkaus: Saavuttamattomuuden semantiikka Kaija Saariahon oopperassa. Acta Musicologica Fennica 27. Helsinki: Suomen Musiikkitieteellinen \& Yliopistopaino.

Hautsalo, Liisamaija (2008b) Isän tyttö. Käsiohjelma Suomen Kansallisoopperan Isän tyttö -tuotantoon. Helsinki: Suomen Kansallisooppera.

Heiniö, Mikko (1989) Lähtökohtia oopperatutkimukseen. Musiikkitiede 2, ss. 66-94.

Heiniö, Mikko (1995) Suomen musiikin historia 4: Aikamme musiikki. Helsinki: WSOY.

Heiniö, Mikko (1999) Karvalakki kansakunnan kaapin päällä: kansalliset attribuutit Joonas Kokkosen ja Aulis Sallisen julkisuuskuvassa. Helsinki: Suomalaisen kirjallisuuden seura.

Hosiasluoma, Yrjö (2003) Kirjallisuuden sanakirja. Helsinki: WSOY.

Kivi, Aleksi (1984) Seitsemän veljestä. Teokset 2. Helsinki: Suuri Suomalainen Kirjakerho. Ss. 451678.

Kaasinen, Sari (2008) Nuku, nuku lapseni: Kehtolauluja ja hyräilyhetkiä. Helsinki: Kirjapaja.

Kailas, Uuno (1931) Uni ja kuolema. Helsinki: WSOY.

Knapp, Raymond (2003) Symphonic Metamorphosis. Subjectivity and Alienation in Mahler's Re-Cycled Songs. Middletown: Wesleyan University Press.

Kotilainen, Otto (1924) Koululauluja. Helsinki: WSOY.

Launis, Armas (1915) Ooppera ja puhenäytelmä: Muutamia vertailevia piirteitä. Kansanvalistusseuran toimituksia 171. Helsinki: Raittiuskansan Kirjapaino-Osakeyhtiö. 
Laura-suomennostietokanta (2010) <http://laura.siba.fi/xwiki/bin/view/Laura/WebHome> (luettu 18.08.2010).

Lomax, Alain (1956) Selected Writings. Toim. Ronald D. Cohen. New York: Routledge.

Maalouf, Amin (2004) Kaukainen rakkaus. Libretto. Suom. Jukka Havu. Helsinki: Suomen Kansallisooppera.

Maasalo, Kai (1969) Suomalaisia sävellyksiä II. Melartinista Kilpiseen. Helsinki: WSOY.

Monelle, Raymond (2000) The Sense of Music: Semiotic Essays. Oxford: Princeton University Press.

Monelle, Raymond (2006) The Musical Topic: Hunt, Military and Pastoral. Bloomington: Indiana University Press.

Noske, Frits (1977) The Signifier and Signified: Studies in the operas of Mozart and Verdi. The Hague: Martinus Nijhoff.

O'Callaghan, Clare (2008) "Lullament: Lullaby and lament therapeutic qualities actualized through music therapy". American Journal of Hospice and Palliative Medicine, 25/2, ss. 93-99.

Park, Roh-Kyoung (1997) The Lullaby in Twentieth-century Opera. Painamaton kirjallinen työ tohtorintutkintoon (Doctor of Music). Indiana University.

Pentikäinen, Juha (1990) Suomalaisen lähtö. Kirjoituksia pohjoisesta kuolemankulttuurista. Helsinki: SKS.

Porter, James (2010) "Lullaby". Grove Music Online. Oxford Music Online. <http://www.oxfordmusiconline.com/subscriber/article/grove/music/17160> (luettu 29.10.2010).

Ratner, Leonard G. (1980) Classic Music, Expression, Form, and Style. New York: Schirmer Books.

Rosand, Ellen (2010) Early opera, 1600-90. "Opera (i)." Grove Music Online. <http://www.oxfordmusiconline.com/subscriber/article/grove/music/40726pg3> (luettu 29.10.2010).

Shenfield, Tali, Trehub, Sandra E. \& Nakata Takayuki (2003) "Maternal Singing Modulates Infant Arousal". Psychology of Music. October 31/4, ss. 365-375.

Sivuoja-Gunaratnam, Anne (2003) Musiikkisemiotiikka. Johdatus musiikintutkimukseen. Toim. Tuomas Eerola, Jukka Louhivuori, Pirkko Moisala. Helsinki: Suomen Musiikkitieteellinen Seura. Ss. 271-280.

Survo, Arno (1999) "'"Lyö sie, surma, kurikalla": Kuoleman aiheesta kehtolauluissa." Tuulen jäljillä: kirjoituksia kansanperinteestä ja kulttuurihistoriasta. Toim. Pekka Laaksonen \& Sirkka-Liisa Mettomäki. Helsinki: Suomalaisen Kirjallisuuden Seura. Ss. 148-157.

Tagg, Philipp (2000) Kojak: 50 Seconds of Television Music. Towards the Analysis of Affect in Popular Music (2nd edition). New York: Mass Media Music Scholars' Press.

Tarasti, Eero (1994 [1978]) Myytti ja musiikki: semioottinen tutkimus myytin estetiikasta. Helsinki: Gaudeamus.

Torvinen, Juha (2007) Musiikki ahdistuksen taitona: filosofinen tutkimus musiikin eksistentialis-ontologisesta merkityksestä. Acta Musicologica Fennica 26. Helsinki: Suomen Musiikkitieteellinen Seura.

Välimäki, Susanna (2005) Subject Strategies in Music: A Psychoanalytic Approach to Musical Signification. Acta Semiotica Fennica XXII. Approaches to Musical Semiotics 9. Imatra \& Helsinki: International Semiotics Institute.

Välimäki, Susanna (2008) Miten sota soi? Sotaelokuva, ääni ja musiikki. Tampere: Tampere University Press. 